\title{
How to remove expansive perennial species from sedge-dominated wetlands: results of a long-term experiment in lowland river valleys
}

\author{
Aleksander Kołos $^{1}$ (D) $\cdot$ Piotr Banaszuk ${ }^{1}$ (D)
}

Received: 26 May 2021 / Accepted: 3 October 2021 / Published online: 21 October 2021

(c) The Author(s) 2021

\begin{abstract}
Grasslands belong to valuable ecosystems facing, all over Europe, a drastic decline in their range and loss of species diversity. Severe floristic transformation may result from the cessation of traditional low-input agricultural use, and consequently, the massive spread of perennial herbs and tall grasses. Invaders can quickly form dense stands and displace endemic vegetation, which results in a nearly complete turnover of phytocenoses. In European protected areas, the only legally acceptable means for suppressing alien species and native dominants within protected areas are biological methods and mowing. We investigated the effect of cutting on the presence of three megaforbs: Lysimachia vulgaris, Lythrum salicaria, and Filipendula ulmaria in fen meadows. We hypothesized that long-term, systematic management mimicking a traditional agricultural practice, would suppress the expansion of megaforbs. Management effectively stopped Lysimachia vulgaris only in marshes, where groundwater in the growing season fell deeper than $50 \mathrm{~cm}$. Coverage of Lythrum salicaria fluctuated over the years, while Filipendula ulmaria did not give in to mowing pressure; on the contrary, it increased its coverage in some places. In light of the results of the long-term experiment, we conclude that mowing appeared to be low effective in preventing the spread of tall perennials. It was likely that indirect factors caused the local withdrawal of megaforbs, i.e., mowing-driven stimulation of other species' development (e.g., Carex spp., Phragmites) that outcompete Lysimachia vulgaris.
\end{abstract}

Keywords Białowieża forest $\cdot$ Mowing $\cdot$ Expansive plants $\cdot$ Wetland $\cdot$ Megaforbs $\cdot$ Sedge meadows

\section{Introduction}

Open wet meadows are part of the most valuable and diverse ecosystem in Europe (Pärtel et al. 2005). The species richness in these meadows has developed as a result of centuries of extensive use: grazing of drier grasslands and mowing of wet meadows. As open grasslands are sensitive to changes in management and hydrology, a transformation in agriculture that began in the late nineteenth century in Western Europe and in the middle of the twentieth century in Central and Eastern Europe has led to a drastic decline in the range of grasslands (Tye 1991) and far-reaching transformations in species composition (Diekmann et al. 2019). The most likely

Aleksander Kołos

a.kolos@pb.edu.pl

Piotr Banaszuk

p.banaszuk@pb.edu.pl

1 Department of Agri-Food Engineering and Environmental Management, Białystok University of Technology,

Białystok, Poland cause of the dramatic loss of habitats and species diversity in wet grasslands is the intensification of agricultural use on those lands: drainage, fertilization, and a higher mowing frequency, as has been demonstrated in northern Germany, where over $60 \%$ of plant species have disappeared within the last 6-7 decades (Immoor et al. 2017). Floristic changes that may be as severe as those from intense agricultural use may result from the abandonment of use coupled with progressive dewatering of wetland habitats caused by climate change (Trąba and Wolański 2011), which is particularly evident in Central Europe and the Baltic States (Joyce 2014).

A distinct shift in species composition of wet grasslands observed throughout Europe encompasses the loss of rare species (Vogt-Schilb et al. 2015) or an increased abundance of tall grasses (Prach 2008) or herbs (Falińska 1989). Many abandoned grasslands are invaded by perennial herbs, the most common of which are Lythrum salicaria, Lysimachia vulgaris, and Filipendula ulmaria. Due to vigorous generative reproduction (Lythrum salicaria), vegetative reproduction (Lysimachia vulgaris) or simultaneous vegetative and generative reproduction (Filipendula ulmaria; Falińska 
1991), these species can relatively quickly form dense stands and displace endemic vegetation, which results in a nearly complete turnover of phytocenoses (Diekmann et al. 2019). In North America, Lysimachia vulgaris and Lythrum salicaria are documented as having a detrimental impact on native wetland plant communities and associated wildlife, and they are treated as invasive species threatening native wetland biodiversity (Blossey 1999; Messick and Kerr 2007; Dodds and Whiles 2010), although impact of Lythrum salicaria is controversial (Lavoie 2010).

Suppression of invaders is difficult, and studies in the literature on that topic produce contrasting results. The positive effect of a return to traditional low-input agricultural practices is usually emphasized. Mowing, in addition to controlled grazing, is a frequent and most obvious prescription for the management of open, seminatural non-forest ecosystems. As mowing has been shown to be effective in preventing the spread of trees and shrubs during secondary succession and by weakening the effect of competitive species, it contributes to the preservation of species richness (Bakker 1989; Diemer et al. 2001; Wahlman and Milberg 2002).

However, numerous experiments noted the inefficiency of the mechanical eradication of invaders. Mowing once a year was suggested to be insufficient for the maintenance of the floristic structure of eutrophic Calthion meadows, as it was found to support tall species such as Carex sp. or Glyceria maxima (Rosenthal 1992; Schrautzer et al. 1996). Since mowing, prescribed burning, and flooding are supposed unsuccessful (Galatowitsch et al.1999), control techniques for Lythrum salicaria and Lysimachia vulgaris are limited relying on the application of herbicides (glyphosate) and hand-pulling (NRCS 2006; Warne 2016). Extensive use of glyphosate in agriculture, gardening, and landscaping is a growing concern worldwide (Kanissery et al. 2019); thus, management plans of many European protected areas, including Natura 2000, have introduced restrictions on the use of pesticides (OECD 2016). The European Commission has expressed the urgent need to reduce dependency on pesticides and plans to reduce the use of chemical pesticides in agriculture by $50 \%$ by 2030 (COM 2020). Currently, in the $\mathrm{EU}$, the only broadly acceptable methods for reducing the coverage of alien species and native dominants are biological methods and mowing. However, the management details, such as the number of swaths per year and their duration and timing, are still controversial.

This paper aims to fill this knowledge gap. The objective of our long-term experiment was to investigate the effect of vegetation management on the distribution and morphology of selected megaforb species within sedge meadow communities in a lowland river valley. We hypothesized that longterm, systematic mowing, mimicking a traditional agricultural practice, would suppress the expansion of megaforbs. Since long-term ecological and environmental studies are considered crucial for the understanding of the functioning of ecological communities and linkages between environment and biological patterns (Hughes et al. 2017), we hope that our results can contribute to progress in grassland ecology and improvements in environmental policy.

\section{Materials and methods}

\subsection{Study area}

The research encompassed the Narewka River and the Chwiszczej River valleys situated in the Białowieża Forest (NE Poland) (Fig. 1).

The Narewka R. is a small left-bank tributary of the Narew River. The catchment takes the area of $710.7 \mathrm{~km}^{2}$, of which near $50 \%$ is covered by forests. The research was conducted in the Reski range (N 52 $42^{\prime} 36.55^{\prime \prime}$, E23 $3^{\circ} 9^{\prime} 48.88^{\prime \prime}$; 149.9-152.0 $\mathrm{m}$ a.s.1.) located in the southern part of the Białowieża National Park. The valley subject to recurring flood events and is filled with minerogenous peat. In the central part of lowering the thickness of histosols amounts to nearly $150 \mathrm{~cm}$. Towards the plateau's edge, the peat thickness decreases to $60-70 \mathrm{~cm}$, and further on, histosols turn into mollic gleysols (Kołos 2011). Inundation of this part of the Narewka valley lasts only for a short time during the spring snow-melt period. Throughout the year, groundwater stays below ground, and its depth varies depending on floodplain morphology. It lays between 15 and $36 \mathrm{~cm}$ in paludified parts and $45-168 \mathrm{~cm}$ in elevated and drier locations (Pierzgalski et al. 2002). The Narewka R. valley was deforested about 200 years ago (Faliński 1966) and turned into wet meadows and grasslands. Low intensive agricultural use has ceased in the late 1970s. Abandoned meadows have subjected to secondary plant succession and are currently dominated by sedge and rush communities as well as initial bog-alder forests (Falińska 1991). Marshes border on an extensive complex of riparian forest dominated by Alnus glutinosa, Fraxinus excelsior and Picea abies.

The Chwiszczej River is a small watercourse with a length of $13 \mathrm{~km}$ and a catchment of $35.5 \mathrm{~km}^{2}$. The upper course of the valley is narrow and covered by crop fields (Niczyporuk and Wiater 2006). The lower section of Chwiszczej R. valley (the Dubiny range; N52 $41^{\prime} 17.39^{\prime \prime}$, E23 $3^{\circ} 35^{\prime} 22.20^{\prime \prime}$; $154.2-155.0 \mathrm{~m}$ a.s.1.) is a $1 \mathrm{~km}$ wide, dominated by sedge communities and rushes, with patches of meadows, megaforbs and willow thickets. A substantial part of the valley floor is covered with Alnus glutinosa woodlands (Tyszka 2008). The valley is filled with a shallow murshic histosols with a thickness varying between 0.5 and $1.5 \mathrm{~m}$. The Chwiszczej R. valley is usually flooded in early spring, and in some years, the flood extends until the end of May. This inundation 


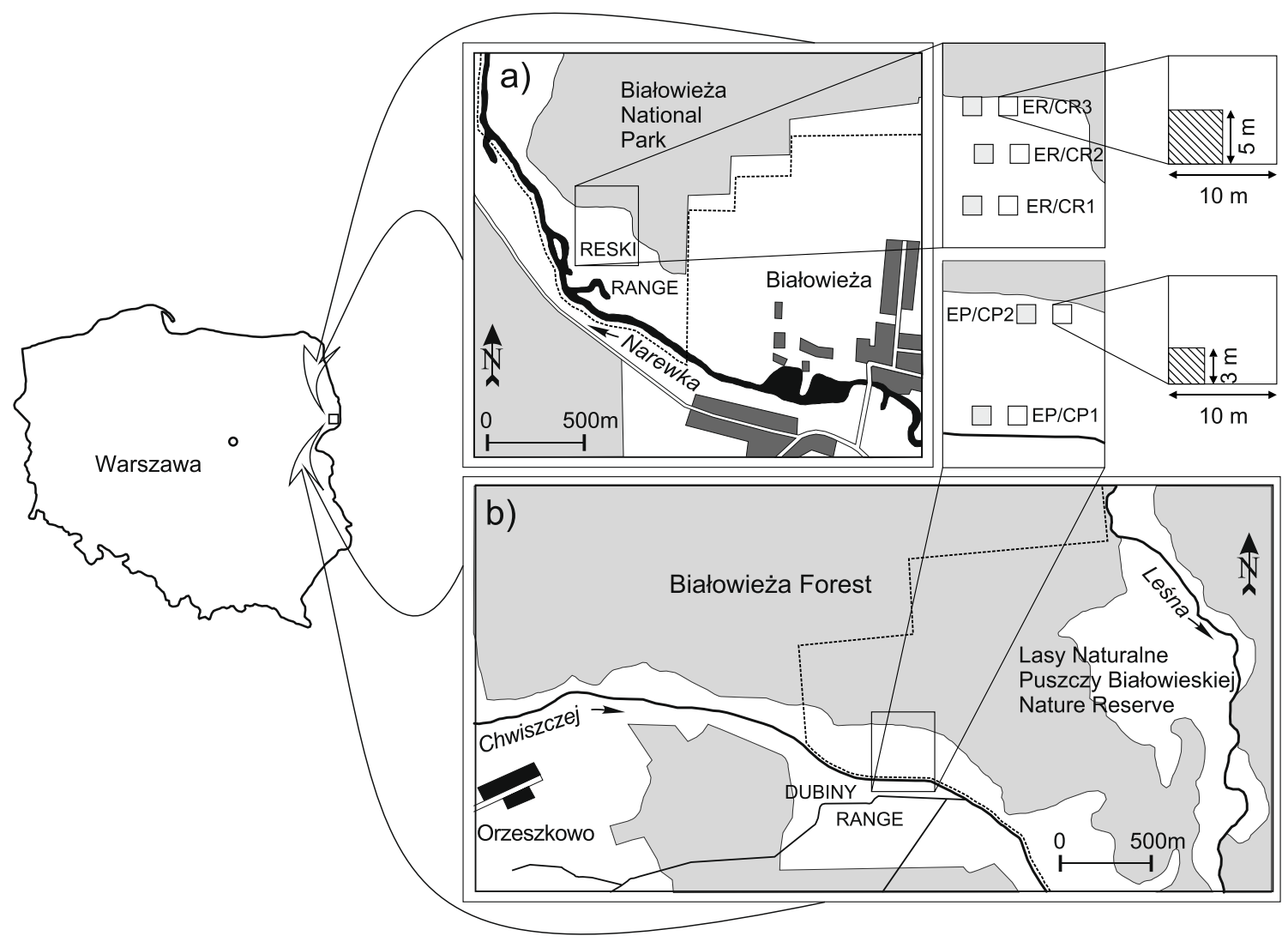

Fig. 1 Location of the study sites in the Narewka River (a) and the Chwiszczej River (b) valleys. The right top panels show the distribution of the primary research plots (ER/CR; EP/CP) and exemplary subplots within which the occurrence of megaforbs was mapped (hatched squares)

occurs almost every year, even though regulations were developed for the entire river length in the mid-twentieth century. The depth of the floodwater ranges from a few to $>40 \mathrm{~cm}$. It is always deeper and long-lasting in backswamps in the marginal zone of the valley than in other areas. At the end of the growing season (August-October), the groundwater level in the valley decreases to several dozen centimeters below ground level, especially in its central parts. Currently, the valley is managed only in its upper reaches. Meadows and pastures have not been used in the swampy part of the valley since 1980. In 2003, this part of the valley was included in the nature reserve "Lasy Naturalne Puszczy Białowieskiej”.

In NE Poland, the mean air temperature is $7.1^{\circ} \mathrm{C}$, and the average rainfall is $596 \mathrm{~mm} \mathrm{yr}^{-1}(1951-2020)$. Permanent snow cover occurs over 70-80 days on average every year between late December and early March. The snow depth reaches up to $80 \mathrm{~cm}$; however, milder temperatures in recent decades resulted in less winter snowfall and a significant drop in the snow depth. The growing season lasts 180-200 days (https://danepubliczne.imgw.pl).

\subsection{Vegetation study; mowing experiment}

We conducted the mowing experiment in the Narewka valley in the years 1985-2000. Three experimental plots (ER) and three control plots (CR) were distributed in pairs within the marsh. One pair of plots (ER1, CR1) was located on a slightly dried, elevated part of the valley closer to the river bed, while the second one (ER2, CR2) was situated in a wet ground depression closer to the edge of the valley. The third pair of plots (ER3, CR3) was placed in a well-moistened marginal part of the valley, in the transition zone between alder forests and sedge meadows communities. The study plots $(10 \times 10 \mathrm{~m})$ were divided into four smaller units of $5 \times 5 \mathrm{~m}$ each. Experimental plots were surrounded by a "buffer" $2 \mathrm{~m}$ wide to minimize the neighboring plant communities' edge effect.

The experimental plots were annually mown by hand scythe at the beginning of July to mimic the traditional land use. The biomass was immediately removed after cutting. The distribution of selected plants, including three species of megaforb, Lysimachia vulgaris, Lythrum 
salicaria, and Filipendula ulmaria, was mapped on a scale of 1:20. We mapped the vegetation structure on experimental and control plots before mowing, within one, previously randomly selected square of $5 \times 5 \mathrm{~m}$. To increase the accuracy of mapping in the field, we divided the plots into 25 smaller squares with an area of $1 \mathrm{~m}^{2}$ each. For the clonal species, their coverage in aggregations and the distribution of individual shoots were marked. Vegetation structure was mapped during mowing experiment in 1985, 1990, 1995, 2000 and repeated in 2007, seven years after cessation of mowing.

To compare data showing the spatial distribution of megaforb species within the plots $(5 \times 5 \mathrm{~m})$, cartograms were divided into 400 quadrates $(0.25 \times 0.25 \mathrm{~m})$. On this basis, the frequency of these perennial species was calculated for further analysis.

Long-term experiment on the impact of mowing in the Chwiszczej valley was conducted from 2006 to 2019. Observations encompassed two pairs of research plots (experimental/control) located in the central zone (EP1/CP1) and nearedge zone (EP2/CP2) of the valley. Each of them had an area of $100 \mathrm{~m}^{2}(10 \times 10 \mathrm{~m})$. The experimental plots were annually mown by hand scythe at the beginning of July. We removed the biomass immediately after mowing. Experimental plots were surrounded by $2 \mathrm{~m}$ wide "buffer".

Structural-forming species, including three species of megaforb, Lysimachia vulgaris, Lythrum salicaria and Filipendula ulmaria, were mapped (scale of 1:20) on research plots at the beginning of July, before the treatment in the years 2006, 2009 and 2019. We mapped $3 \times 3 \mathrm{~m}$ squares randomly established for all four primary research areas (EP and $\mathrm{CP}$ ). The frequency of occurrence of megaforbs within the research plots $(3 \times 3 \mathrm{~m})$ was calculated on the basis of cartograms divided into 144 squares $(0.25 \times 0.25 \mathrm{~m})$. In addition, on each experimental and control plot, morphometric studies of Lysimachia vulgaris were conducted on ten $1 \times 1 \mathrm{~m}$ squares, which were previously selected within the study plots. The numbers of generative and vegetative shoots were counted, and their heights were measured (Kołos and Banaszuk 2021a). Among megaforbs occurring in the plant patches, only Lysimachia vulgaris appeared with a large coverage; therefore, morphometric studies were postponed for the other two species.

In the Chwiszczej R. valley the groundwater level was monitored once a month (each time in the first week of the month), between May and November of 2007-2019, in two wells located in the vicinity of the research plots (Kołos and Banaszuk 2021b). Electrical conductivity (EC) was measured in situ using a CPC-411m (Elmetron, Poland). Samples of groundwater were analyzed photometrically for concentrations of N-NO ${ }_{3}^{-}, \mathrm{N}_{-} \mathrm{NH}_{4}{ }^{+}$, and $\mathrm{P}_{-} \mathrm{PO}_{4}{ }^{3-}$ (Slandi LF-205, Poland). $\mathrm{Ca}^{2+}$ was determined by titration with a standardized solution of ethylenediaminetetraacetic acid (EDTA).
For the Narewka R. marshes, we used a river volumetric flow rate (https://danepubliczne.imgw.pl) as a proxy of the wetland's hydrology dynamic. A seasonal decomposition procedure (multiplicative model) was used to divide the Narewka discharge time series into three components: trend-cycle, seasonality and irregular.

The significance in the differences between the samples was tested by ANOVA and the nonparametric two-sample K-S test. A bivariate density plot was used to display the joint distribution of the height and number of shoots of Lysimachia vulgaris. The general linear model (GLM) procedure was applied to predict the impact of management (categorical factor) and hydrology (quantitative factors) on the number of vegetative shoots of Lysimachia vulgaris. All statistical analyses were performed by Statgraphics19 software (Statgraphics Technologies, Inc. The Plains, Virginia, USA).

\section{Results}

\subsection{Hydrology and groundwater dynamics}

In the Chwiszczej River valley, the groundwater depth during the vegetation season differed significantly $(F=9.66$; df 1,$186 ; p<0.05)$ depending on the morphology of the valley bottom. Between April and October, the groundwater occurred on average at a depth of $-5 \pm 24 \mathrm{~cm}$ in the back swamp, while on the natural levee close to the stream, groundwater was at a depth of $-16 \pm 25 \mathrm{~cm}$. Throughout the growing season, water level occurred with the highest frequency between +10 and $-10 \mathrm{~cm}$ in the central zone and between 0 and $+20 \mathrm{~cm}$ in the near-edge zone of the valley. In this location, a second mode near $-50 \mathrm{~cm}$ below the ground surface reflected the lowered water supply by overbank flooding and atmospheric precipitation.

Records show the seasonal pattern of groundwater rise occurring in early spring in April-May and in some years occurring in autumn. In both locations, the maximum flood reached $+40 \mathrm{~cm}$ in depth. The lowest groundwater stage is typical for the dry period of June and between September and October when a depth of $<-30 \mathrm{~cm}$ is commonly seen. Records compiled for the 14 years of observations showed continued dewatering of the swamp, with the groundwater depth diminishing annually (Fig. 2). In recent years, the water table dropped well below $-50 \mathrm{~cm}$ and even to $>-100 \mathrm{~cm}$ in the elevated parts of the valley bottom. In the summer months of 2018 and 2019, no inundation of the wetland occurred.

A similar pattern of water dynamics, within a year and along the multiannual period, was observed in the Narewka valley. "Wet" years with high spring discharges were 1986, 1988 and 1996, while stream flows lower than the average were recorded e.g. in 1990, 1992, 1995 and 1997 (Fig. 3). 


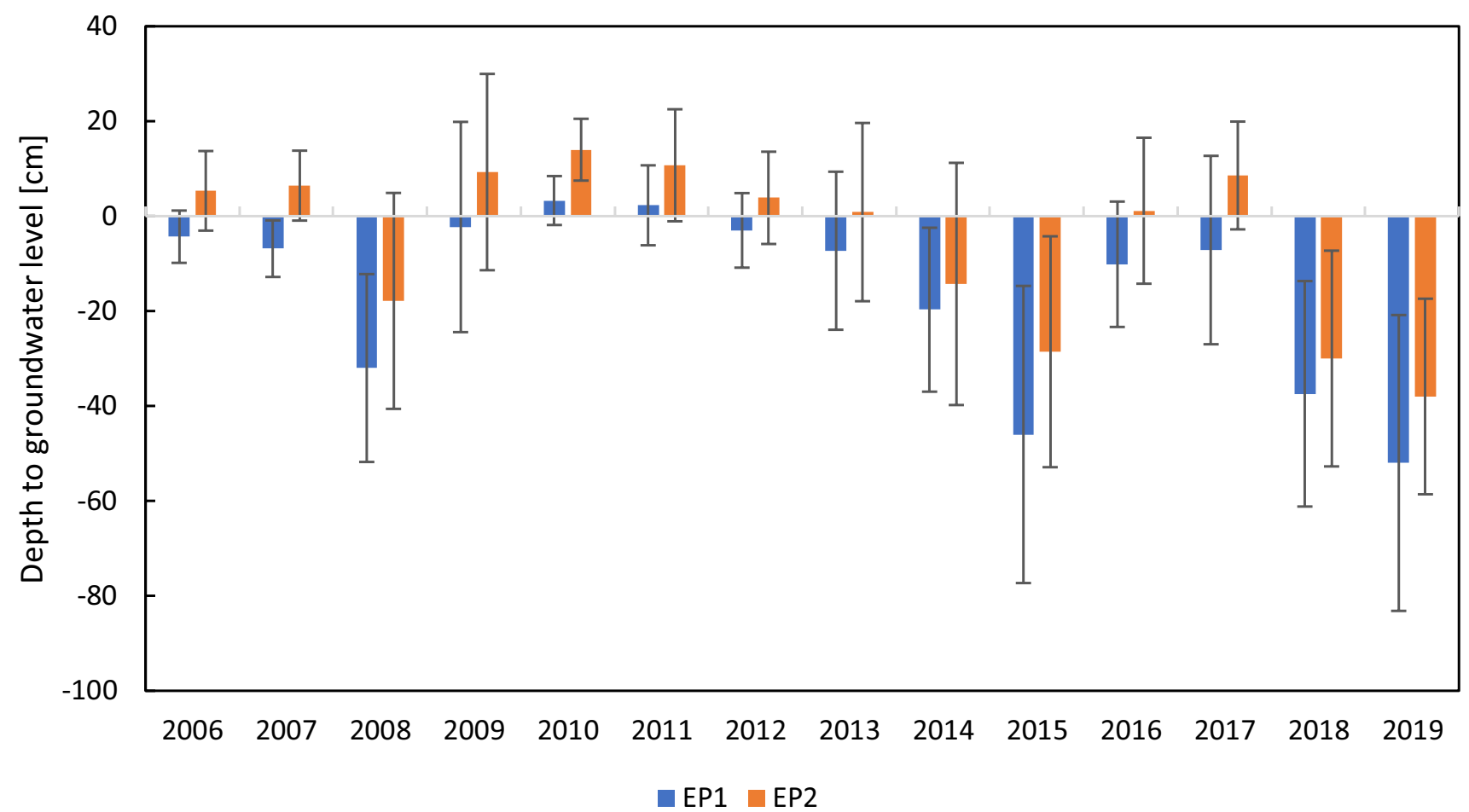

Fig. 2 Changes in the average depth to groundwater level during growing season April-October in years 2006-2019 on natural Chwiszczej R. levee (EP1) and in the back-swamp (EP2); error bars \pm 1 SD. Differences among plots are statistically significant $(F=9.66 ;$ df 1,$186 ; p<0.05)$

In Chwiszczej marshes the electrical conductivity of groundwater in the middle part of the valley averaged 311.9 $\mu \mathrm{S} \cdot \mathrm{cm}^{-1}$ (ranging between 271 and $400 \mu \mathrm{S} \cdot \mathrm{cm}^{-1}$ ) and was significantly lower $(p<0.05)$ than that in the marginal zone fed by the groundwater discharged from adjacent uplands, where the mean EC totaled $418 \mu \mathrm{S} \cdot \mathrm{cm}^{-1}\left(284-597 \mu \mathrm{S} \cdot \mathrm{cm}^{-1}\right)$. We observed only a weak link between EC and groundwater level. A statistically significant $(p<0.05)$ directly proportional relationship was found for the late summer-early autumn months. In the wetter years with shallow inundation of the valley, an input of river water refreshed the composition of the groundwater and led to an increase in the EC. There was no clear trend in the EC of the groundwater.

The groundwater had relatively low $\mathrm{N}_{-} \mathrm{NO}_{3}{ }^{-}$at concentrations of $0.20 \pm 0.19 \mathrm{mg} \cdot \mathrm{L}^{-1}$ near the stream location and $0.06 \pm 0.07 \mathrm{mg} \cdot \mathrm{L}^{-1}$ at the valley margin. The concentrations of $\mathrm{N}^{-\mathrm{NH}_{4}}{ }^{+}$were $0.69 \pm 0.44$ and $0.23 \pm 0.25 \mathrm{mg} \cdot \mathrm{L}^{-1}$, respectively, and those of $\mathrm{P}_{-} \mathrm{PO}_{4}{ }^{3-}$ were $0.10 \pm 0.06$ and $0.06 \pm 0.07 \mathrm{mg} \cdot \mathrm{L}^{-1}$, respectively. The content of calcium was higher in the valley margin $\left(70 \pm 14.1 \mathrm{mg} \cdot \mathrm{L}^{-1}\right)$ than in the central zone $\left(48 \pm 7.0 \mathrm{mg} \cdot \mathrm{L}^{-1}\right)$.

\subsection{Changes in megaforb species coverage in the sporadically flooded Narewka R. valley}

Before starting the experiment, megaforbs occupied about $~ 30 \%$ of the experimental plot (ER1) located closer to the river bed. Lysimachia vulgaris and Lythrum salicaria dominated, while Filipendula ulmaria was recorded sporadically (Fig. 4). After 5 years of mowing, the perennials' total share has changed slightly, but we noticed their spread to previously unoccupied areas. In the 10th year of mowing a substantial increase in the coverage of Lysimachia vulgaris (up to 30\%) and a decrease in the abundance of Lythrum salicaria occurred. Both of these species reacted inversely to the following 5 years of management. During the whole experiment, a two-fold increase in Filipendula ulmaria coverage was recorded.

On the ER2 plot, megaforb species occurred with a similar proportion as on the ER1 (Fig. 4). During the experiment the coverage of these plants were fluctuating. After 15 years, Lythrum salicaria showed high coverage despite continued management, while Lysimachia vulgaris 
Fig. 3 Upper panel-the trend-cycle component in the Narewka R. maximum monthly discharge Q (1980-2010) estimated by smoothing the time series data using a simple moving average with span $k$ equal to the length of seasonality $s=12$. Lower panel-seasonally adjusted $\mathrm{Q}$. The original time series was adjusted by removing the seasonal effects and leaving both the trend-cycle and irregular components
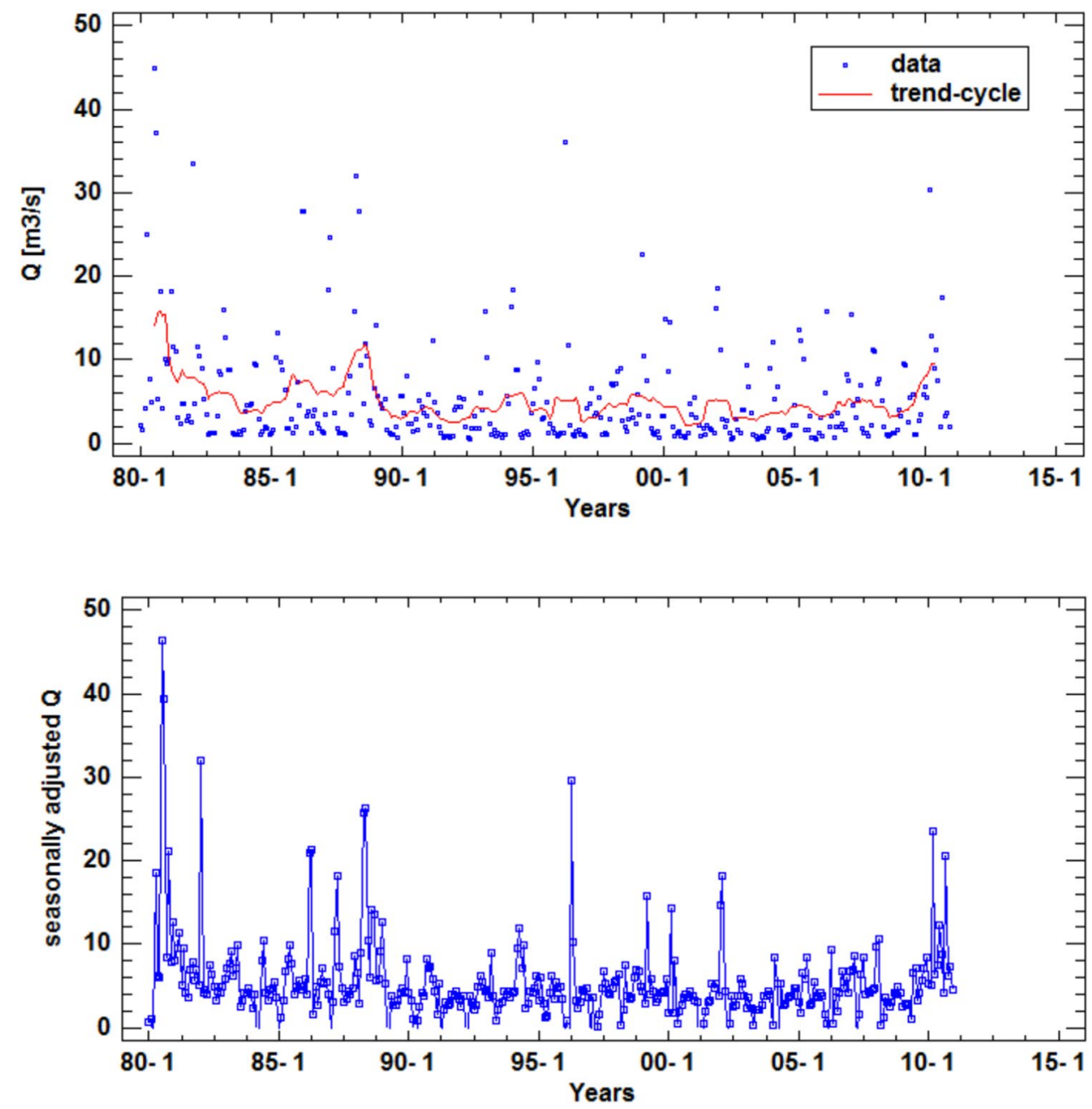

reduced its occurrence to sparse clusters. Similar to the ER1 plot, the coverage of Filipendula ulmaria increased several times due to mowing.

A gradual withdrawal of tall perennials from phytocoenoses subjected to annual mowing in alder forests' ecotone zone (ER3) occurred (Fig. 4). Of the analyzed megaforbs, Filipendula ulmaria showed the least susceptibility to the management.

On unmown (control) patches, megaforbs formed compact clusters more often than on mown ones. On the CR1, we recorded a decrease of Lythrum salicaria and Filipendula ulmaria and a substantial increase in the coverage of Lysimachia vulgaris (from $<1 \%$ in 1985 to a dozen percent in 2000; Fig. 5). The abundance of Lysimachia vulgaris also increased on the CR2. Coverage of Filipendula ulmaria fluctuated over the 15 years of the treatment, while the status of Lythrum salicaria did not change through that time. In the ecotone (CR3), megaforbs, particularly Filipendula ulmaria, tended to withdraw from plant patches.

\subsection{Changes in megaforb species coverage caused by mowing in annually flooded valley (the Chwiszczej River)}

On experimental plot EP1, in the central part of the valley, before the start of the mowing experiment, the proportion of tall herb species reached $30 \%$. During the first four seasons of repetitive mowing, we observed a sharp decrease in coverage of Lysimachia vulgaris (Fig. 6). In subsequent years, only single aboveground shoots of Lysimachia vulgaris appeared. The coverage of Lythrum salicaria also decreased meaningfully, while the spatial coverage of Filipendula ulmaria was maintained virtually unchanged throughout the study period. In the EP2 established in the back swamp, tall forbs initially appeared with low coverage, and only single shoots and clusters were noted (Fig. 7). Annual mowing did not significantly affect their occurrence over a dozen years. A several-fold increase in abundance was observed only for Filipendula 

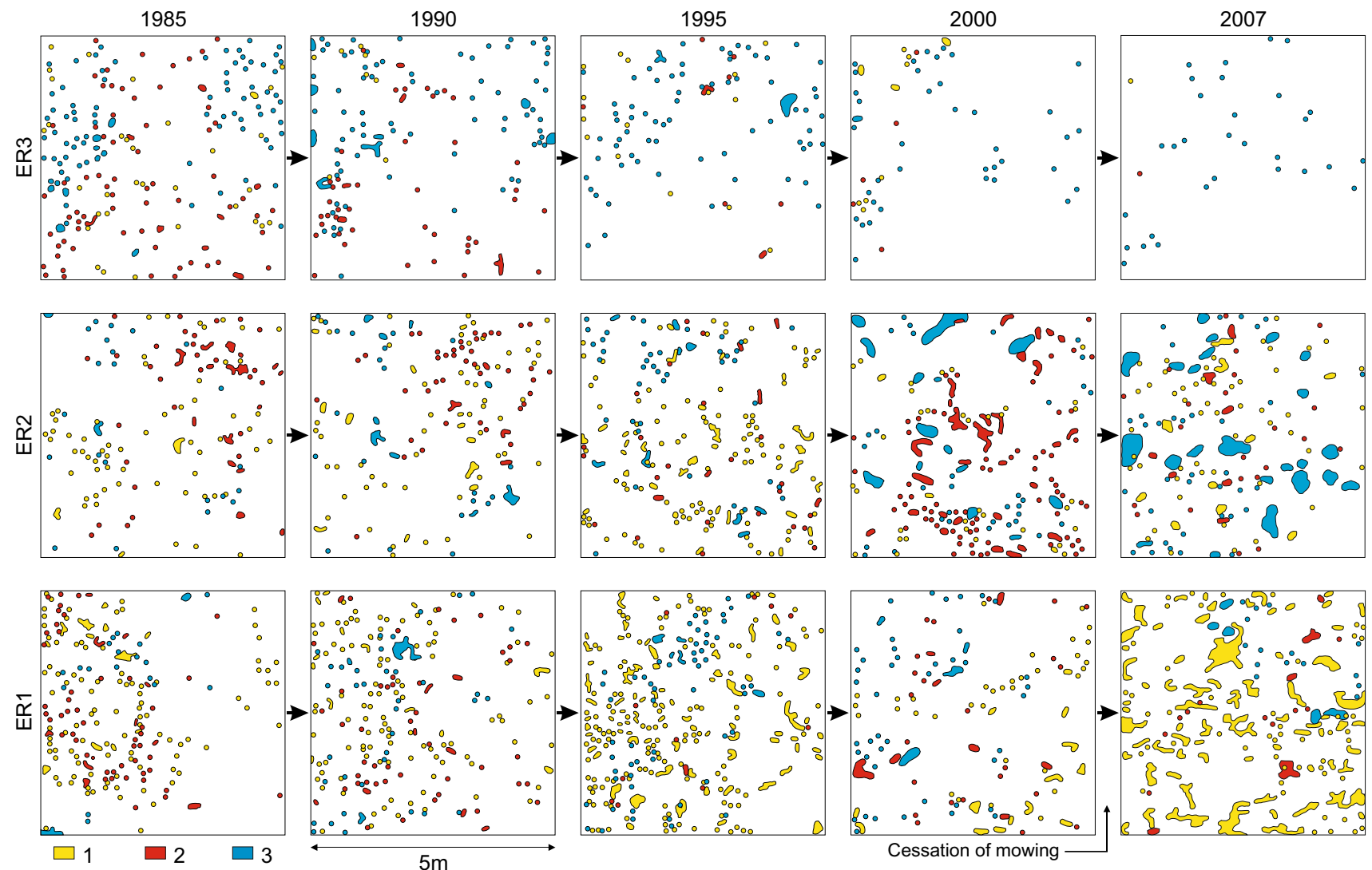

Fig. 4 Dynamic of megaforb species cover during of 23-year (1985-2007) management of sedge meadows patches in the Narewka R. valley. 1-Lysimachia vulgaris, 2-Lythrum salicaria, 3-Filipedula ulmaria; ER-experimental plot

ulmaria, although even then, its coverage reached only a few percent.

There were no changes in the coverage of megaforbs in the control plot CP2 established in the near-edge zone of the valley (Fig. 7). In turn, fluctuations in abundance were noted in the $\mathrm{CP} 1$ plot located near the riverbed. The fluctuations were noticeable only for Lysimachia vulgaris; in the early stages of the experiment, we noted a decrease in coverage from approximately $20 \%$ to several percentage points that was followed by a considerable rise in abundance (to approximately 30\%) in the last years of the study (Fig. 6).

\subsection{Effect of mowing on the density and height of aboveground shoots of Lysimachia vulgaris}

At the experiment's outset, over 150 aboveground shoots of Lysimachia vulgaris per $10 \mathrm{~m}^{2}$ were recorded in experimental plot EP1. After two seasons of management, the number of shoots increased to $230-240$ shoots $/ 10 \mathrm{~m}^{2}$, and in the fourth year of the experiment, this number dropped sharply to approximately 50 shoots (Fig. 8). In subsequent years, few aboveground shoots of Lysimachia vulgaris were recorded, and in the final stages of the experiment, the aboveground shoots totaled only $4-12$ shoots $/ 10 \mathrm{~m}^{2}$. A sharp decrease affected both vegetative and generative shoots. The generative shoots disappeared in the EP1 plot in the fifth year of the experiment (Fig. 9). In control plot CP1, the number of aboveground shoots fluctuated in the range of 71-175 shoots $/ 10 \mathrm{~m}^{2}$ throughout the whole experiment.

In the back swamp, the number of aboveground shoots of Lysimachia vulgaris in both the experimental and control plots remained low throughout the experiment and fluctuated in the range of 7-34/10 $\mathrm{m}^{2}$ (Fig. 8). Only in the first two growing seasons were higher values recorded (38-54 shoots $/ 10 \mathrm{~m}^{2}$ ). During several years of research, no significant changes were noted in the dynamics of the number of generative and vegetative shoots in either the EP2 or CP2 plot (Fig. 9).

The fluctuation in the number of vegetative shoots of Lysimachia vulgaris was correlated with the groundwater level and depth of inundation: in years with high (above surface) groundwater levels, the total number of shoots significantly decreased, and dryer years favored enhanced sprouting of aboveground shoots. Importantly, this dependency was found for the backswamp only in both the experimental and control plots (Fig. 10). In mown plot EP2, vegetative 

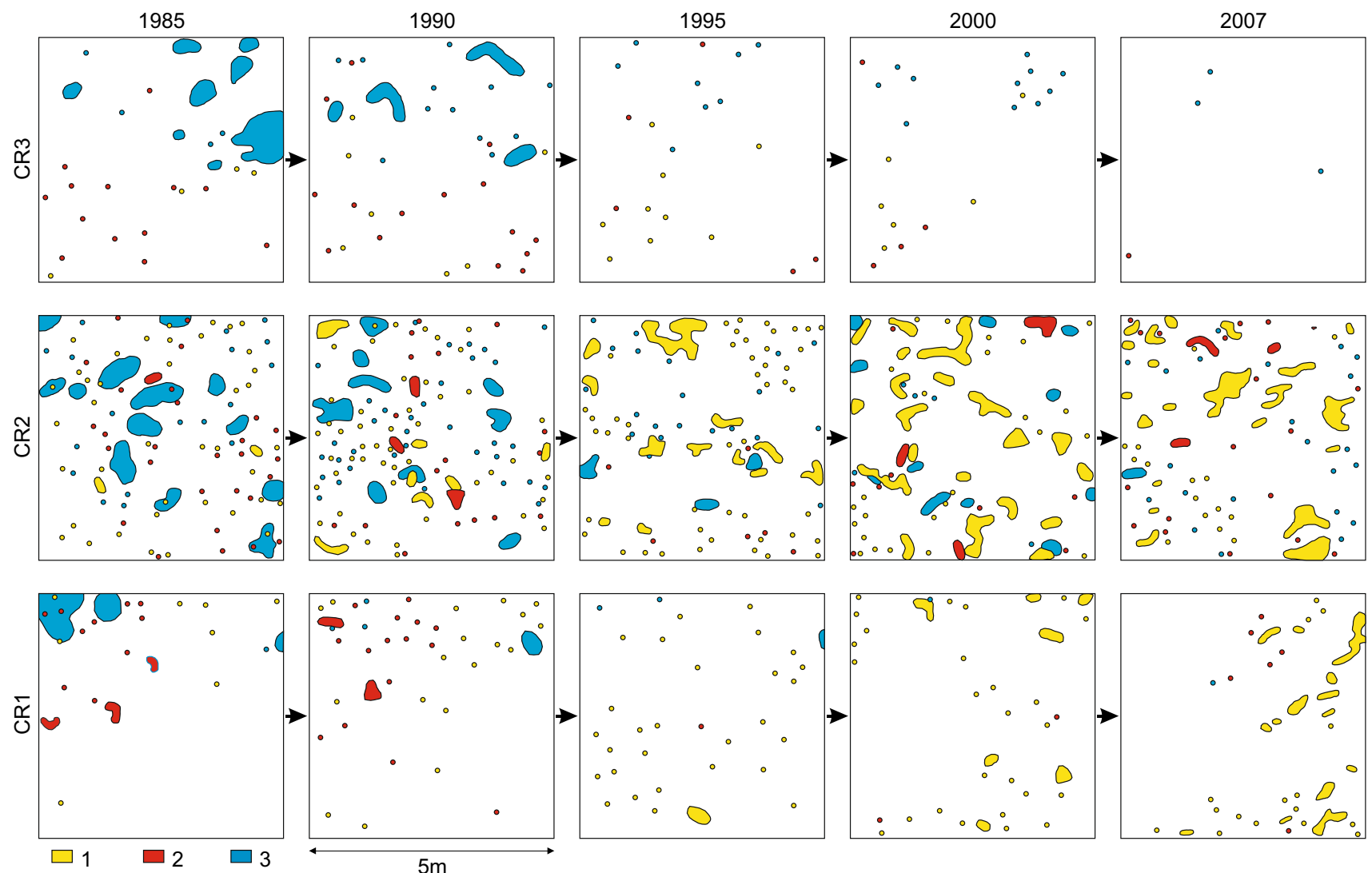

Fig. 5 Dynamic of megaforb species cover on control plots (CR) during of 23-year (1985-2007) mowing experiment performed in the Narewka R. valley. 1-Lysimachia vulgaris, 2-Lythrum salicaria, 3-Filipendula ulmaria

shoots exhibited a statistically significant cross-correlation with antecedent water conditions. Inundation was positively correlated with the number of vegetative shoots with a 2 -year time shift $(p<0.05)$. The number of generative shoots was not related to water dynamics.

We also found a very weak inversely proportional relation between the antecedent water conditions and the number of Lysimachia vulgaris shoots in the Narewka valley. The relationship was, however, statistically insignificant.

The general linear model procedure demonstrated a statistically significant impact of management and hydrology on the number of vegetative shoots of Lysimachia vulgaris $(p<0.05)$ in addition to a significant $(p<0.05)$ two-factor interaction between mowing and maximum groundwater level in the Chwiszczej valley (Fig. 11). Mowing significantly reduced the number of shoots in the absence of flooding. In the increasing depth of a flood, the difference between the number of shoots on the mowed and reference plots decreased and was statistically insignificant.

In the EP1 plot, the number of vegetative shoots of Lysimachia vulgaris was low and usually did not exceed 40 individuals, and their height was similar, ranging from 50 to $55 \mathrm{~cm}$ (Figs. 12, 13). In the EP2 plot, there were only a few shoots, and their height was much more varied. In both zones of the valley, vegetative shoots reached larger heights in the control plots (CP1 63.3 $\pm 18.0 ; \mathrm{CP} 265.0 \pm 21.2 \mathrm{~cm}$ ) than in the experimental plots (EP1 $47.5 \pm 15.6 \mathrm{~cm}$; EP2 $48.2 \pm 17.2 \mathrm{~cm}$; K-S test $p<0.05$; Fig. 13). The same regularity was also noted for generative shoots (CP1 92.2 \pm 13.3 ; CP2 106.3 $\pm 12.2 \mathrm{~cm}$; EP1 $83.2 \pm 9.0 \mathrm{~cm}$; EP2 87.6 \pm 13.3 ). Moreover, generative shoots in the unmown plot on the river levee were significantly lower than those on the unmown area in the back swamp (KS test $p<0.05)$. There was no significant effect of mowing on the height of vegetative shoots in various zones of the valley.

In most cases, the height of both vegetative and generative shoots did not show any relationship with the dynamics of habitat moisture. An inversely proportional relationship was found only for generative shoots and the maximum groundwater level in the experimental plot at the riverbed.

\section{Discussion}

The responses of wet meadow phytocenoses to the introduction of regular mowing have been noted as contrasting. According to some authors, mowing does not eliminate tall 

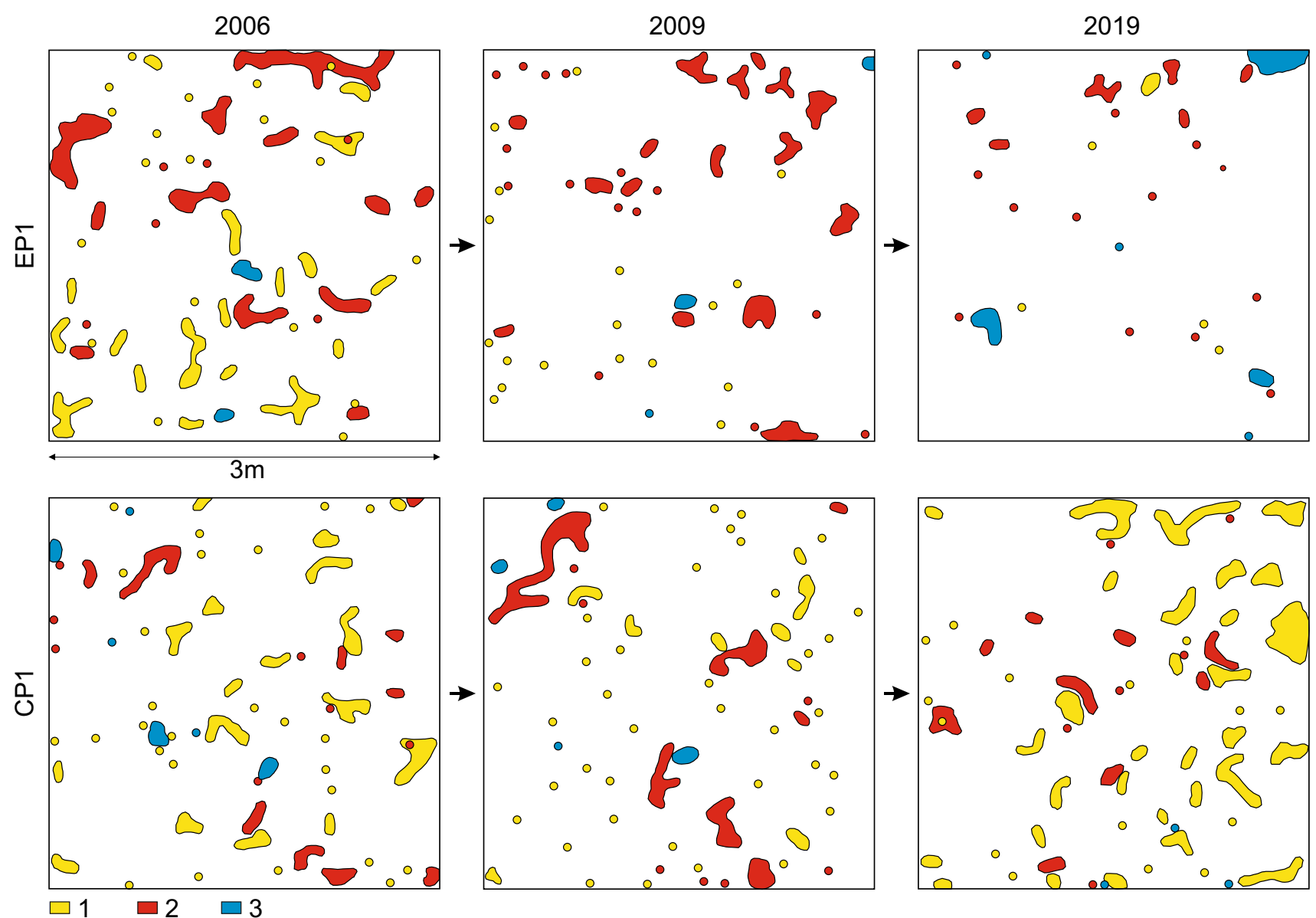

Fig. 6 Dynamic of megaforb species cover during of 14-year (2006-2019) management of sedge meadows on the Chwiszczej R. levee. 1-Lysimachia vulgaris, 2-Lythrum salicaria, 3-Filipendula ulmaria; $\mathrm{EP}$ - experimental plot, $\mathrm{CP}$-control plot

perennials and even promotes their development (Hellström et al. 2006). Their mass appearance called "herbal phases" was found in addition to their "grassy phases," which are the most common and long-lasting alternative stable states of sedge meadow communities subjected to mowing in flooded river valleys (Kołos and Banaszuk 2013).

The essence of these transitions is the increasing coverage of herbaceous plants that before mowing were suppressed by dominants, e.g., Carex acutiformis (Kołos and Banaszuk 2013). Regular disturbance promotes the development of minimally competitive species and perennials that reproduce vegetatively (Metsoja 2016). Management was found to weaken competitors, open gaps in the vegetation canopy, and create microhabitats and diverse plant patches (Poschlod and Biewer 2005). The availability of gaps enables tall-growing perennials to produce more shoots and conquer new spaces within phytocenoses.

The spread of perennials does not run linearly. The change occurs abruptly, often during the first 5 years of the management (Kołos and Próchnicki 2012). Initially, the production of aboveground shoots occurs mainly within the polycormones, without any significant changes in the aerial coverage of perennials. Later on, megaforbs increase their acreage, mainly due to their effective reproduction. The number of offspring that Lysimachia vulgaris and Filipendula ulmaria can annually produce from one parent shoot ranges from 2 to 10 , which supports a lateral spread of hypogeogenous stems up to 0.25 m per year (KostrakiewiczGierałt 2014a). The growth and survival of genets and population spread can be slowed due to the restrictive effects of necromass (Falińska 1991, 1995).

Other experiments have produced opposite results and demonstrated that most tall herbs do not tolerate mowing pressure (Mitchley and Willems 1995; Valkó et al. 2012; Temu et al. 2015). According to Fynn et al. (2004), early cutting of bud tops reduces the flowering and fruiting of tall perennials and eliminates them slowly from phytocenoses. A significant mowing effect was confirmed by the authors of this study in the Narewka River and Chwiszczej River wetlands, where a long-term manipulation of a sedge meadow resulted in nearly complete elimination of Lysimachia vulgaris or a significant reduction in the species cover. The 


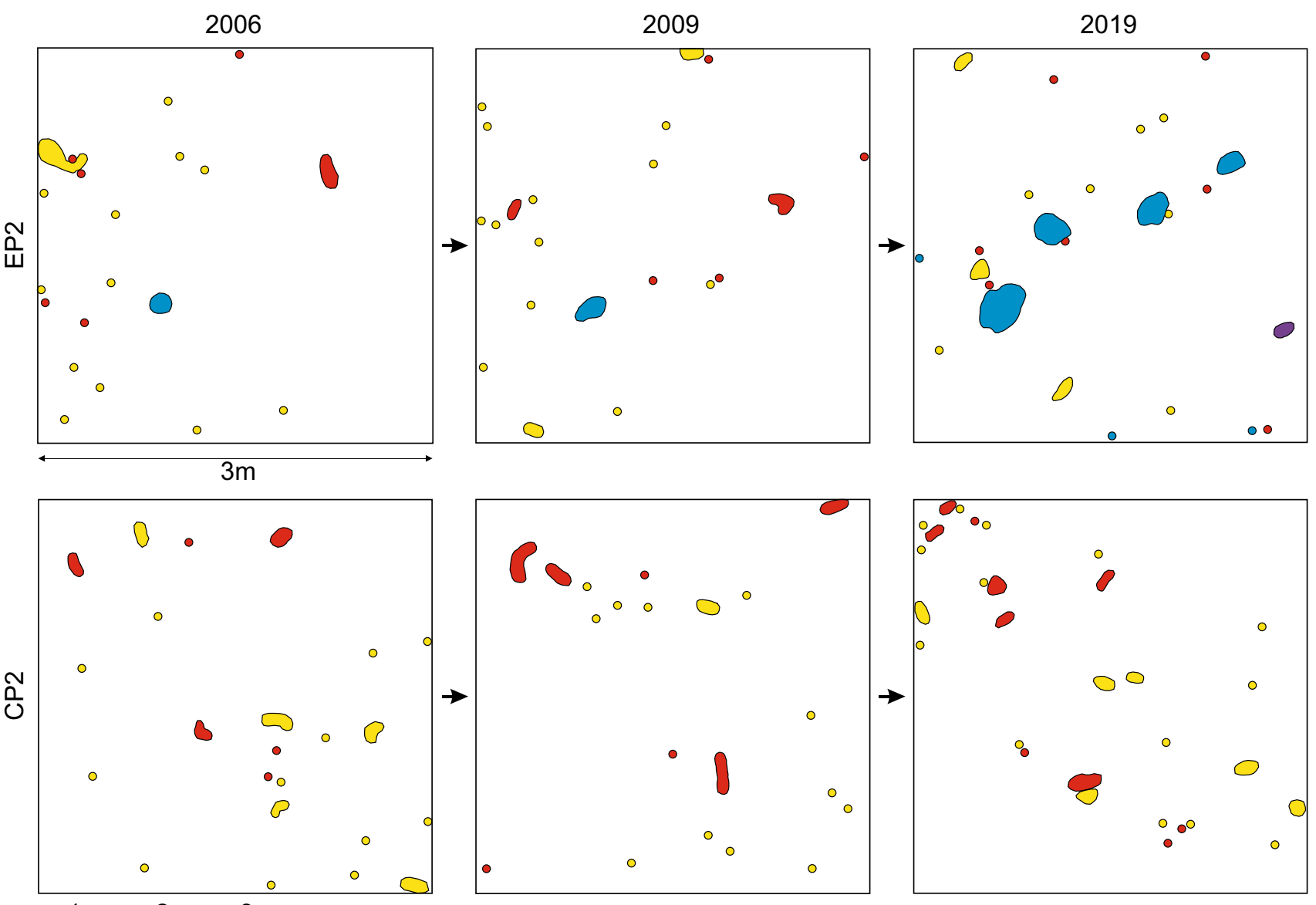

$\square 1 \square 2 \square 3$

Fig. 7 Dynamic of megaforb species cover during of 14-year (2006-2019) management of sedge meadows patches in the Chwiszczej R. backswamp. 1-Lysimachia vulgaris, 2-Lythrum salicaria, 3-Filipendula ulmaria; EP—experimental plot, CP-control plot

duration and intensity of management are likely to control the vegetation shift trajectory only in the first years of management (Huhta 2001; Schaffers 2002); however, weather conditions and the soil water regime may profoundly modify the effect of management (Kołos and Banaszuk 2013, 2018).

\subsection{Perennial herbs in dryer, elevated part of wetland}

In the Chwiszczej River wetland, removal of biomass led to a disappearance of Lysimachia vulgaris and Lythrum salicaria but only in elevated, drier parts of the valley bottom, such as a fluvial levee. During the growing season, raised fragments of valley bottom had significantly lower groundwater levels, and in drier years with a lower sum of precipitation (2008, 2015, 2018, and 2019), when the groundwater level dropped to $50 \mathrm{~cm}$ and even $100 \mathrm{~cm}$ below the ground level, considerable water deficits occurred that remained for weeks. Under water shortages, tall perennials seem to react intensively to the stress caused by mowing. In drying meadow patches, management induced enhanced vegetative reproduction of competitive creeping sedge and grass species (Carex acutiformis, C. acuta, Calamagrostis canescens), forming a dense, compact cover (Kołos and Banaszuk 2013; Kołos-unpublished data), which challenges the development of herbaceous plants, including perennials. As a result, herbaceous plants have already retreated from the mown meadow in the early years of management. Similar changes, although not so pronounced, were also observed during the experiment conducted in the Narewka valley (ER1 plot).

Therefore, it seems that mowing supports the removal of herbs indirectly by modifying the vegetation structure and triggering the development of species competing with perennials rather than directly affecting Lythrum salicaria and Lysimachia vulgaris. However, both vegetative and generative shoots of Lysimachia vulgaris were significantly lower in the mowed plots than in the unmanaged control plots.

Interestingly, in the unmanaged plots, tall herbs retained the spatial status quo or even increased their coverage. The height and number of Lysimachia vulgaris shoots fluctuated over the study period, but the changes were not related to 

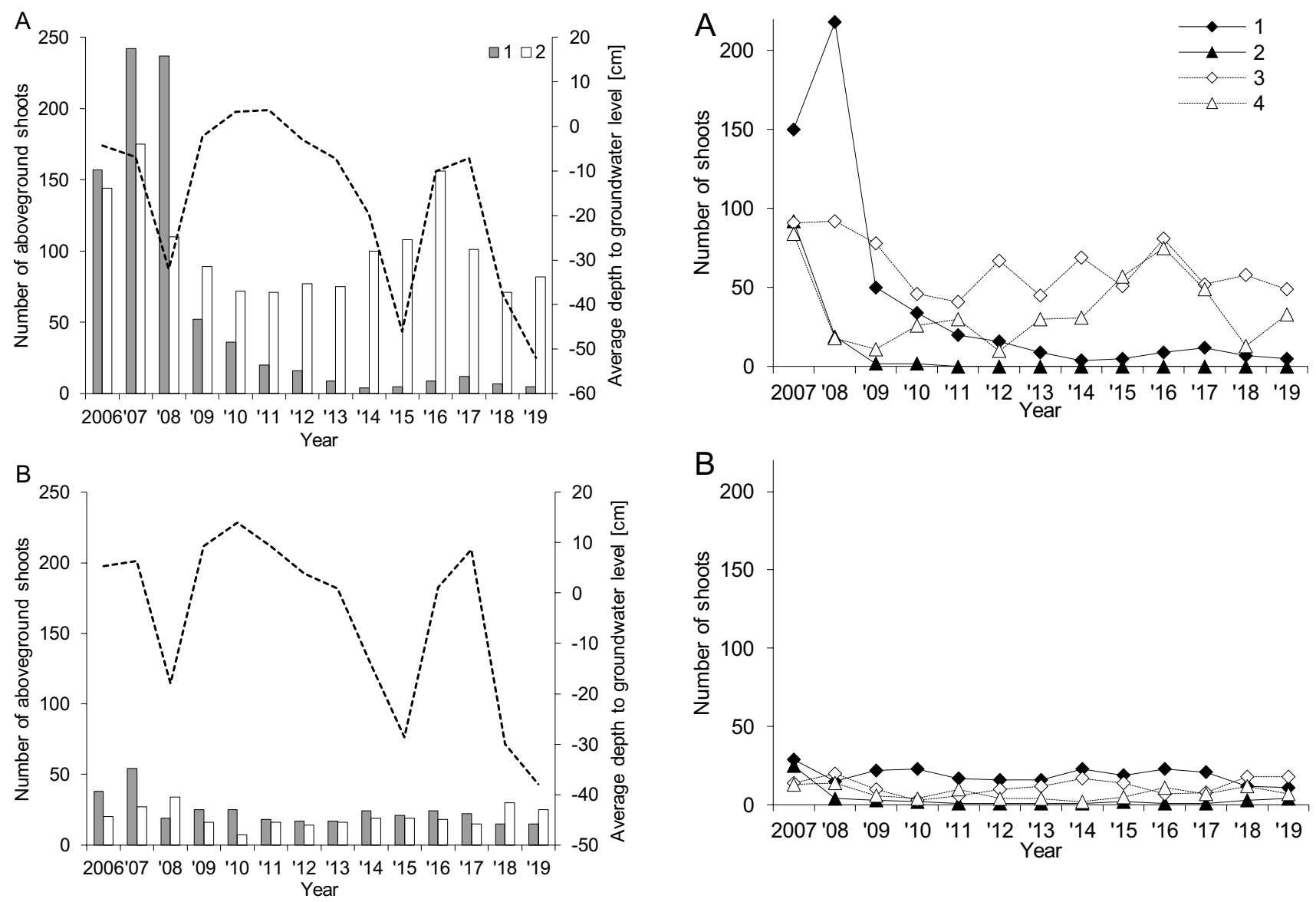

Fig. 8 Changes in the number of above-ground shoots of Lysimachia vulgaris during of 14-year (2006-2019) management of sedge meadows on the Chwiszczej R. levee (A) and in back-swamp (B). Shoots were counted on ten $1 \mathrm{~m}$ squares located within each experimental (1-EP1, EP2) and control (2-CP1, CP2) plots

soil moisture. This result seems to support the observation by Blossey and Schroeder (1995) that well-established populations of Lythrum salicaria are able to persist for years even in drier habitats. Another explanation may be related to the relative abundance of gaps available for colonization as well as the positive impact of the surrounding intact vegetation on the survival of individuals, especially at the early stages of their life (e.g., in Lysimachia vulgaris, see Kelemen et al. 2015).

\subsection{Perennials in wetter depressions in the valley bottom}

Backswamp plants rarely experience water shortages. Even in dry years with a low amount of precipitation, changes in the groundwater level are much less pronounced because possible water deficits are replenished by capillary rise supported by the "hydraulic-lifting" suction of tussock sedges (Peach and Zedler 2006), which enhances the moisture

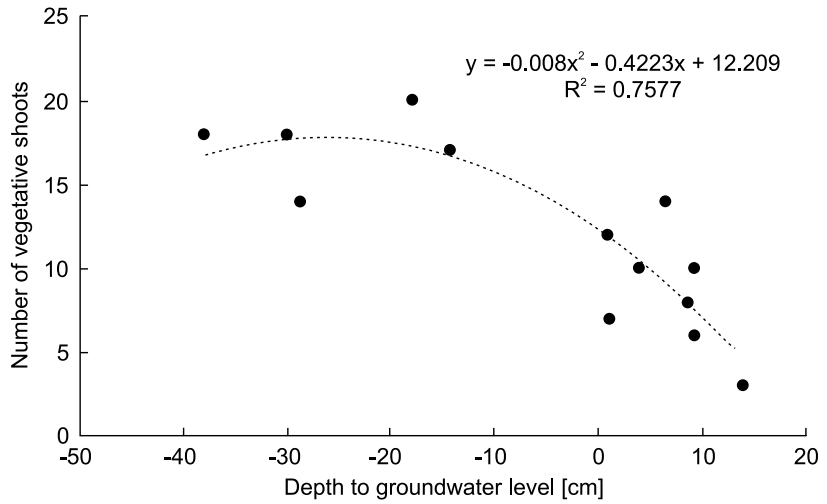

Fig. 10 Relationship between the number of vegetative shoots of Lysimachia vulgaris and average depth of groundwater in control plot CP2 in back-swamp; $p<0.01$ 


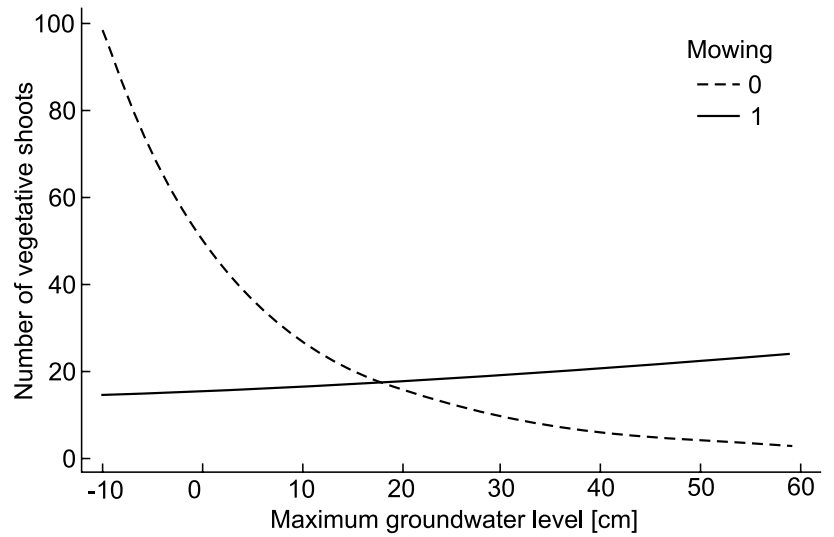

Fig. 11 Result of general linear model procedure. The interaction plot displays the least squares means at all combinations of two factors: inundation and mowing affecting the number of vegetative shoots of Lysimachia vulgaris. For response variable Box-Cox transformation was applied: power $=-0.174578$ shift $=0$
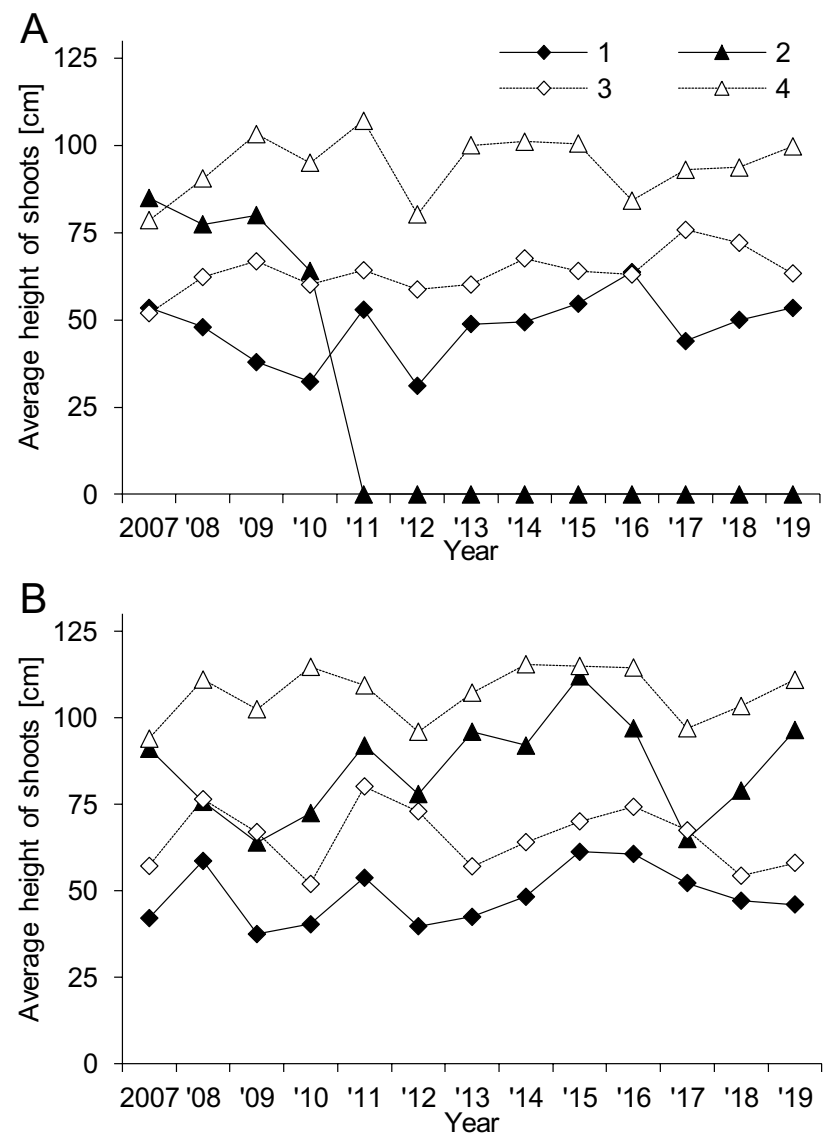

Fig. 12 Changes in average height of shoots of Lysimachia vulgaris during of 14-year (2006-2019) management of sedge meadows in the elevated-drier (A) and marginal-wetter (B) part of the Chwiszczej R. valley. Shoots were counted on ten $1 \mathrm{~m}$ squares within each mown (1-vegetative shoots; 2 -generative shoots) and unmown (3-vegetative shoots; 4 -generative shoots) plots of upper soil horizons and alleviates the effect of drought (Caldwell et al. 1998; Leffler et al. 2005). For most of the springtime, the water remained above the soil surface and dropped below the surface in the middle of the summer.

Long-lasting shallow inundation has created specific sedge meadow structures with microhabitats in the form of tussocks and hollows. In the beginning of the growing season, the waterlogged soil is inaccessible to plant seeds, and the majority of herbs grow on sedge tussocks above the level of the flood (Peach and Zedler 2006). Tall herbs, such as Lysimachia vulgaris and Filipendula ulmaria, are among the best colonizers of tussock plants (Kostrakiewicz-Gierałt 2014b).

Perennial herbs on tussocks have not experienced pressure from competing species, and despite the regular impact of mowing, they survived in the plant community. While in individual years the depth of inundation in the Chwiszczej valley fluctuated between 10 and $50 \mathrm{~cm}$, the number of vegetative shoots of Lysimachia vulgaris remained relatively constant (varied between 17 and 23). In the control plot, the number of shoots was apparently controlled by hydrology, and the number decreased in wet years. In well-moistened plant patches in the Narewka valley, Lythrum salicaria and Filipendula ulmaria persisted or even increased their cover despite long-term annual mowing.

The effects of mowing performed in the ecotone of alder forests differed from those achieved during many years of management of open phytocoenoses located away from the forest edge. We observed the gradual retreat of megaforbs from the patches and a reduction in their coverage to just a few shoots on the study plot at the end of the experiment (ER3 plot). The only species that resisted management was Filipendula ulmaria. However, the disappearance of tall perennials in the ecotone was related rather not to long-term use, but to succession and the spread of Phragmites australis, which occur particularly dynamically at the forest border. A specific confirmation of these assumptions is the almost identical course of changes observed on the control plots established in the ecotone.

\subsection{Timing of management}

Establishing mowing (in our experiment at the turn of June and July) before the ripening of Lysimachia vulgaris is an important factor in slowing the spread of this species in sedge meadow communities. Dillon and Reichard (2014) demonstrated that the seeds of Lysimachia vulgaris germinate most abundantly and effectively after surviving winter dormancy, as the vernalization process is a prerequisite for effective germination (Falińska 1981). Cutting the aboveground shoots of this plant before seed ripening reduces the amount of seeds deposited in the soil bank. However, generative reproduction of Lysimachia vulgaris 

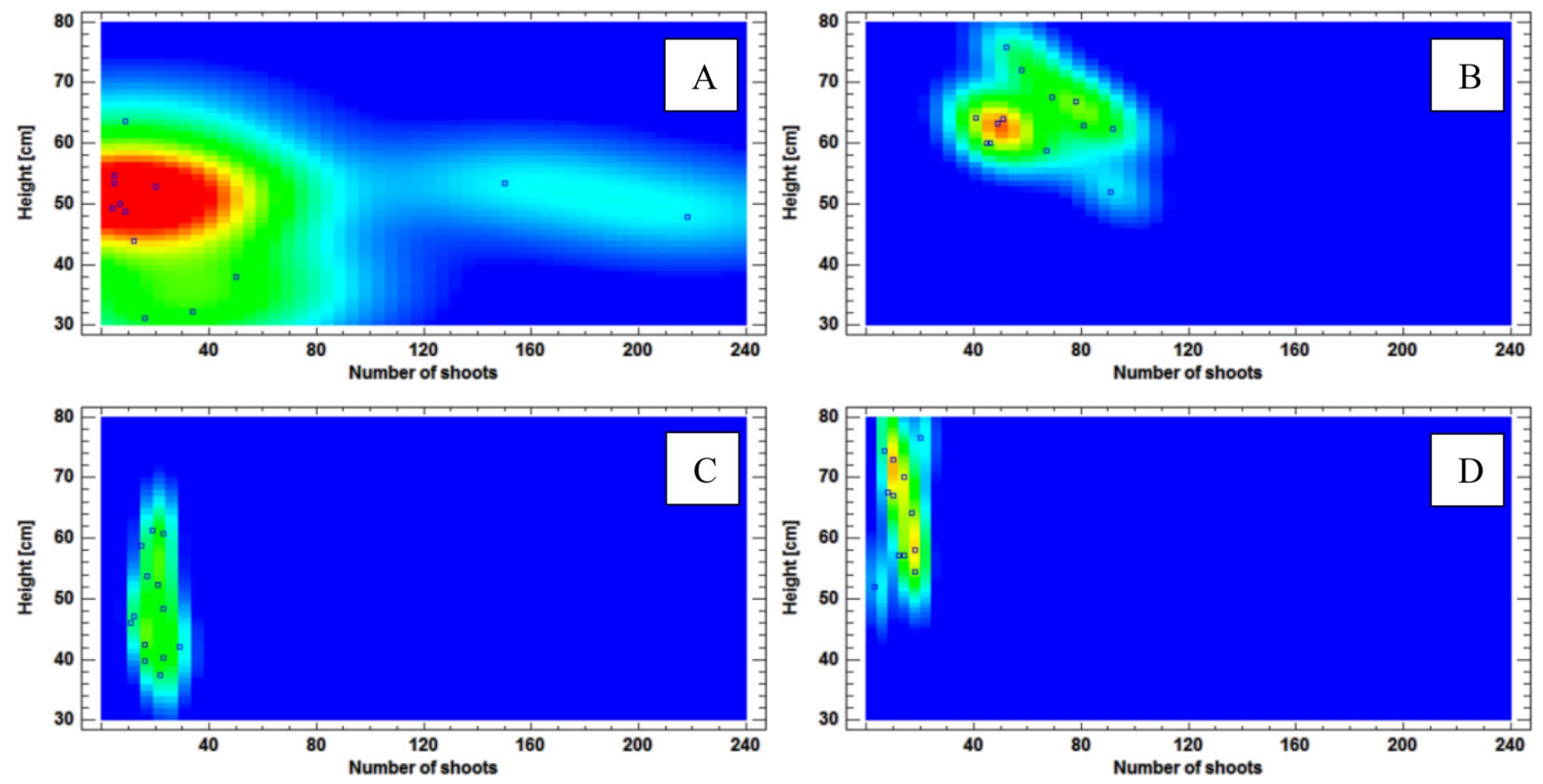

Fig. 13 Bivariate density plot-frequency histogram for the height and number of shoots of Lysimachia vulgaris (nonparametric density estimate with width 60\%). Upper panel—fluvial levee: A mown plot

EP1, B control CP1; lower panel-back-swamp: C mown plot EP2, D control CP2. Notice significantly (KS test, $p<0.05$ ) greater height of shoots on the control plots

is of marginal importance. Individuals derived from seeds rarely appear in natural populations (Morozowska 2004), although seedlings of herbaceous species usually occur abundantly in plant patches (Franczak and Czarnecka 2016). The absolute dominance of vegetative over generative reproduction of megaforb species (Morozowska 2004) suggests that it was mowing and not the seed bank in the soil that caused the different responses of the herbaceous species to vegetation manipulation in the nearstream (drier) and near-edge (wetter) parts of the river valley. Consequently, the timing of management can be viewed as at least a secondary factor. However, this only concerns the removal of expansive plant species, but not the restoration of the species composition, as the timing of management may be critical for increasing the diversity of plant species of disturbed semi-natural ecosystems.

The experiment by Wilcox (1989) showed that Lythrum salicaria populations can be controlled by repeated mowing. However, due to this species' specific reproductive characteristics, caution should be exercised when implementing mechanical control. Plants should be removed before seed development to prevent seed bank enrichment, and the treatment should be performed in dry places on hot days to prevent the regrowth of shoots from cut plants.

\subsection{Limitation of the study}

Our experiment's key value lays in its duration since most studies on the effect of repeated management of wetlands vegetation are limited to a few years, which is much too short in time to allow vegetation to reach an equilibrium state (Faliński 1998). Though, the experimental design may resemble a shortage of replication, which may provide a risk that some of the observed patterns could be contextdependent, thus lacking universal importance.

However, we believe that there are arguments that support our approach, and make obtained results to give rise to some generalizations despite the doubts of being pseudoreplicated. Lack of replication is common in ecological studies (Hurlbert 1984). The standard type of "controlled" experiment may involve a "single replicate" per treatment because replications are often impossible or undesirable when large-scale or unique objects are studied. Thus, the concept of "pseudo-replication" is sometimes viewed as unjustified stigmatization of reasonable tests of specific ecological systems (Oksanen 2001). Studies on a small number of experimental and control plots precisely identified vegetation's ecological processes (Falińska 1997; Schrautzer et al. 2011). 
Fig. 14 The response of magaforb species to long-term annual mowing of sedge meadows. On the wet soils with long-lasting inundation, their abundance did not follow a consistent trend. They appear to be in dynamic equilibrium with their environment and undergo short-term fluctuations. Mowing drastically reduces Lysimachia vulgaris in dry habitats

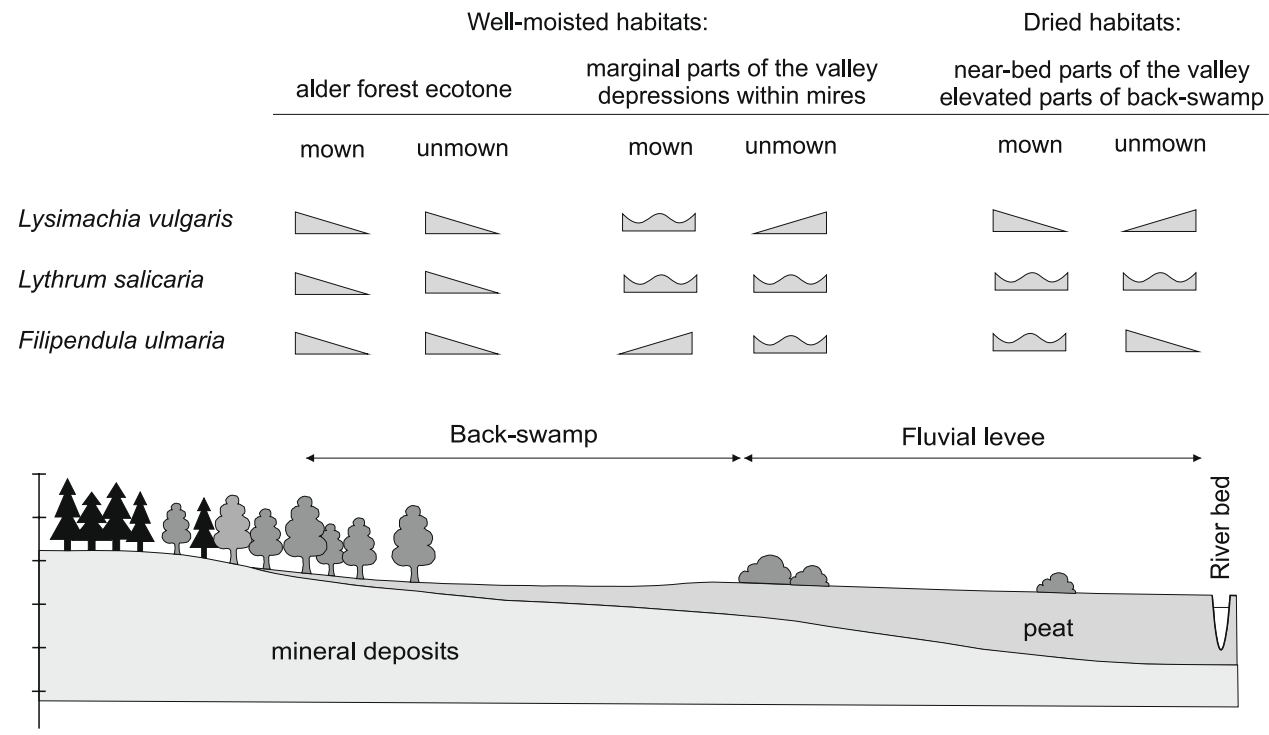

The long-term impact of mowing on sedge meadows' phytocoenoses could be credibly resolved by examining protected object excluded from agricultural use; in our case, it was the Białowieża National Park, nature reserve Lasy Naturalne Puszczy Białowieskiej and a Natura 2000 site. This approach seems to reflect phytocoenosis's reaction to management in a distinct environmental condition context while eliminating short-term anthropogenic impacts. However, the decision to investigate a national park and a nature reserve is linked with numerous restrictions, limiting negative impacts on biota, including research activities.

\subsection{Conclusions and implications of the results}

Invasive native and nonnative species spreading in wetlands can damage ecosystem services and biota (Malecki et al. 1993; Keller et al. 2011). Thus, adequate protection of biodiversity often requires stopping the spread of dominant species regardless of their geographical origin (Houlahan and Findlay 2004).

Lythrum salicaria and Lysimachia vulgaris are serious invaders of many types of wetlands in North America, where they are a threat to many sensitive wetland ecosystems. In Central Europe, the group of species reaching dominant status in degraded and mown wetlands includes, apart from tall perennials, grasses (e.g., Phragmites australis and Phalaris arundinacea). In many cases, the changes resulting in perennial herb expansion are large and alarming enough to take countermeasures to reduce their numbers in the invaded ecosystems. Depending on local conditions, three primary methods are used: herbicide spraying, mowing, and controlled fires (Messick and Kerr 2007; Whittle et al. 2007; Knezevic et al. 2018).
Due to the restricted use of herbicides in protected areas in many European countries, biological and mechanical methods remain the only acceptable way for reducing the coverage of both alien species and native dominants. The effectiveness of biological approaches (e.g., through Coleoptera release) is sometimes questionable. According to McAvoy et al. (2016), biological agents have successfully reduced the abundance of megaforbs only when their density was low.

Our results show a limited efficiency of cutting in preventing the growth of tall perennials (Fig. 14). Management effectively stops Lysimachia vulgaris only in marshes, where groundwater in the growing season decreases to lower than $50 \mathrm{~cm}$, and the mowing effect was rather indirect by stimulating the spread of other species (e.g., Carex spp., Phragmites) that outcompete Lysimachia vulgaris. Coverage of Lythrum salicaria fluctuated under the influence of long-term annual mowing. The only species that did not react to annual mowing was Filipendula ulmaria, and throughout many years of management, it not only was a permanent component of wet sedge meadows but also even increased its coverage on well-moistened habitats with longer inundation, which was also described Huhta (2001) and Stammel et al. (2003).

Acknowledgements This research was supported by Białystok University of Technology (grant WZ/WB-IIŚ/1/2020). We acknowledge the support of Regional Directorate for Environmental Protection in Białystok and Białowieża National Park.

Author contributions AK designed the study and performed field research, $\mathrm{AK}$ and $\mathrm{PB}$ analyzed data, $\mathrm{PB}$ performed statistical analyses; $\mathrm{AK}$ and $\mathrm{PB}$ wrote the paper and discussed the results. 
Funding This research was supported by Białystok University of Technology (grant WZ/WB-IIŚ/1/2020).

Availability of data and materials The datasets generated during and/ or analysed during the current study are available in the BoxBiaman repository, https://box.biaman.pl/d/b5c0e294730e45cf8e4c/

Code availability Not applicable.

\section{Declarations}

Conflict of interest We have no conflicts of interest to disclose.

Open Access This article is licensed under a Creative Commons Attribution 4.0 International License, which permits use, sharing, adaptation, distribution and reproduction in any medium or format, as long as you give appropriate credit to the original author(s) and the source, provide a link to the Creative Commons licence, and indicate if changes were made. The images or other third party material in this article are included in the article's Creative Commons licence, unless indicated otherwise in a credit line to the material. If material is not included in the article's Creative Commons licence and your intended use is not permitted by statutory regulation or exceeds the permitted use, you will need to obtain permission directly from the copyright holder. To view a copy of this licence, visit http://creativecommons.org/licenses/by/4.0/.

\section{References}

Bakker JP (1989) Nature management by grazing and cutting. Kluwer Academic Publishers, Dordrecht

Blossey B (1999) Before, during and after: the need for long-term monitoring in invasive plant species management. Biol Invasions 1:301-311. https://doi.org/10.1023/A:1010084724526

Blossey B, Schroeder D (1995) Host specificity of three potential biological control agents attacking flowers and seeds of Lythrum salicaria (purple loosestrife). Biol Control 5:47-53. https://doi. org/10.1006/bcon.1995.1006

Caldwell MM, Dawson TE, Richards JH (1998) Hydraulic lift: consequences of water efflux from the roots of plants. Oecologia 113:151-161. https://doi.org/10.1007/s004420050363

COM 2020. 381 final. A farm to fork strategy for a fair, healthy and environmentally-friendly food system. Brussels, 20.5.2020. https://eur-lex.europa.eu/legal-content/ENd/TXT/?uri=CELEX: 52020DC0381. Accessed 10 July 2020

Diekmann M, Andres Ch, Becker T, Bennie J, Blüml V, Bullock JM, Culmsee H, Fanigliulo M, Hahn A, Heinken T, Leuschner Ch, Luka S, Meißner J, Müller J, Newton A, Peppler-Lisbach C, Rosenthal G, van den Berg LJL, Vergeer P, Wesche K (2019) Patterns of long-term vegetation change vary between different types of semi-natural grasslands in Western and Central Europe. J Veg Sci 30:187-202. https://doi.org/10.1111/jvs.12727

Diemer M, Oetiker K, Billeter R (2001) Abandonment alters community composition and canopy structure of Swiss calcareous fens. Appl Veg Sci 4:237-246. https://doi.org/10.1111/j.1654109X.2001.tb00492.x

Dillon K, Reichard SH (2014) Effect of temperature on the seed germination of garden loosestrife (Lysimachia vulgaris L.). Nat Areas J 34:212-215. https://doi.org/10.3375/043.034.0210

Dodds WK, Whiles MR (2010) Freshwater ecology: concepts and environmental applications of limnology, 2nd edn. Elsevier, Amsterdam
Falińska K (1981) Eksperymentalne badania biologii populacji wieloletnich roślin zielnych. Wiad Bot 3:209-230

Falińska K (1989) Plant population processes in the course of forest succession in abandoned meadows. I. Variability and diversity of floristic compositions, and biological mechanisms of species turnover. Acta Soc Bot Pol 58:439-465. https://doi.org/10.5586/ asbp. 1989.036

Falińska K (1991) Plant demography in vegetation succession. Kluwer Academic Publishers, Dordrecht

Falińska K (1995) Genet disintegration in Filipendula ulmaria: consequences for population dynamics and vegetation succession. $\mathrm{J}$ Ecol 83:9-21. https://doi.org/10.2307/2261146

Falińska K (1997) Life history variation in Cirsium palustre and its consequences for the population demography in vegetation succession. Acta Soc Bot Pol 66:207-220. https://doi.org/10.5586/ asbp.1997.027

Faliński JB (1966) Antropogeniczna roślinność Puszczy Białowieskiej jako wynik synantropizacji naturalnego kompleksu leśnego. RozprawyUniwersytetu Warszawskiego 13, pp 1-256

Faliński JB (1998) Dioecious woody pioneer species (Juniperus communis, Populus tremula, Salix sp. div.) in the secondary succession and regeneration. Phytocoenosis (N.S.) 10. Suppl Cartogr Geobot 8:1-256

Franczak M, Czarnecka B (2016) Necromass as seed reservoir in macroforb meadows with varied moisture conditions. Acta Agrobot 69:1693. https://doi.org/10.5586/aa.1693

Fynn RWS, Morris CD, Edwards TJ (2004) Effect of burning and mowing on grass and forb diversity in a long-term grassland experiment. Appl Veg Sci 7:1-10. https://doi.org/10.1111/j.1654-109X. 2004.tb00589.x

Galatowitsch S, Budelsky R, Yetka L (1999) Revegetation strategies for northern temperate glacial marshes and meadows. In: Streever W (ed) An international perspective on wetland rehabilitation. Springer, Dordrecht, pp 225-241

Hellström K, Huhta A-P, Rautio P, Tuomi J (2006) Searchfor optimal mowing regime-slow community change in a restoration trial in northern Finland. Ann Bot Fennici 43:338-348

Houlahan JE, Findlay CS (2004) Effect of invasive plant species on temperate wetland plant diversity. Conserv Biol 18:1132-1138. https://doi.org/10.1111/j.1523-1739.2004.00391.x

Hughes BB, Beas-Luna R, Barner AK, Brewitt K, Brumbaugh DR, Cerny-Chipman EB, Close SL, Coblentz KE, de Nesnera KL, Drobnitch ST, Figurski JD, Focht B, Friedman M, Freiwald J, Heady KK, Heady WN, Hettinger A, Johnson A, Karr KA, Mahoney B, Moritsch MM, Osterback A-MK, Reimer J, Robinson J, Rohrer T, Rose JM, Sabal M, Segui LM, Shen Ch, Sullivan J, Zuercher R, Raimondi PT, Menge BA, Grorud-Colvert K, Novak M, Carr MH (2017) Long-term studies contribute disproportionately to ecology and policy. Bioscience 67:271-281. https://doi. org/10.1093/biosci/biw 185

Huhta A-P (2001) Restorative mowing on semi-natural grasslands: community-level changes and species-level responses. Oulu University Press, Oulu http://jultika.oulu.fi/files/isbn9514259947.pdf. Accessed 18 December 2020

Hurlbert SH (1984) Pseudoreplication and the design of ecological field experiments. Ecol Monogr 54:187-211. https://doi.org/10. $2307 / 1942661$

Immoor A, Zacharias D, Müller J, Diekmann M (2017) A re-visitation study (1948-2015) of wet grassland vegetation in the Stedinger Land near Bremen, North-western Germany. Tuexenia 37:271288. https://doi.org/10.14471/2017.37.013

Joyce CB (2014) Ecological consequences and restoration potential of abandoned wet grasslands. Ecol Eng 66:91-102. https://doi.org/ 10.1016/j.ecoleng.2013.05.008

Kanissery R, Gairhe B, Kadyampakeni D, Batuman O, Alferez F (2019) Glyphosate: its environmental persistence and impact on 
crop health and nutrition. Plants 8:499. https://doi.org/10.3390/ plants8110499

Kelemen A, Lazzaro L, Besnyői V, Albert Á-J, Konečná M, Dobay G, Memelink I, Adamec V, Götzenberger L, de Bello F, Le BagoussePinguet Y, Lepš J (2015) Net outcome of competition and facilitation in a wet meadow changes with plant's life stage and community productivity. Preslia 87:347-361

Keller RP, Geist J, Jonathan M, Jeschke JM, Kühn I (2011) Invasive species in Europe: ecology, status, and policy. Environ Sci Eur 23:23. https://doi.org/10.1186/2190-4715-23-23

Knezevic SZ, Osipitan OA, Oliveira MC, Scott JE (2018) Lythrum salicaria (purple loosestrife) control with herbicides: multiyear applications. Invas Plant Sci Manage 11:143-154. https://doi. org/10.1017/inp.2018.17

Kołos A (2011) Dynamika strefy przejścia między zbiorowiskami leśnymi i nieleśnymi na przykładzie doliny Narewki w Puszczy Białowieskiej. Oficyna Wydawnicza Politechniki Białostockiej, Białystok

Kołos A, Banaszuk P (2013) Mowing as a tool for wet meadows restoration: effect of long-term management on species richness and composition of sedge-dominated wetland. Ecol Eng 55:23-28. https://doi.org/10.1016/j.ecoleng.2013.02.008

Kołos A, Banaszuk P (2018) Mowing may bring about vegetation change, but its effect is strongly modified by hydrological factors. Wetlands Ecol Manage 26:879-892. https://doi.org/10. 1007/s11273-018-9615-x

Kołos A, Banaszuk P (2021a) Chwiszczej River_Lysimachia vulgaris. https://box.biaman.pl/d/b5c0e294730e45cf8e4c/

Kołos A, Banaszuk P (2021b) Chwiszczej River_Groundwater level. https://box.biaman.pl/d/b5c0e294730e45cf8e4c/

Kołos A, Próchnicki P (2012) Long-term effects of annual mowing on spatial structure of sedge meadows in vicinity of riparian forests. Pol J Ecol 60:107-122

Kostrakiewicz-Gierałt K (2014a) The effects of successional stage and size of gaps on recruitment of clonal plants in overgrowing Molinietum caeruleae meadows. Acta Agrobot 67:87-98. https://doi.org/10.5586/aa.2014.044

Kostrakiewicz-Gierałt K (2014b) Are Deschampsia caespitosa (L.) Beauv. tussocks safe sites for seedling recruitment in the succession of wet meadows? Pol J Ecol 62:707-721. https://doi. org/10.3161/104.062.0414

Lavoie C (2010) Should we care about purple loosestrife? The history of an invasive plant in North America. Biol Invasions 12:1967-1999. https://doi.org/10.1007/s10530-009-9600-7

Leffler AJ, Peek MS, Ryel RJ, Ivans CY, Caldwell MM (2005) Hydraulic redistribution through the root systems of senesced plants. Ecology 86:633-642. https://doi.org/10.1890/04-0854

Malecki RA, Blossey B, Hight SD, Schroeder D, Kok LT, Coulson JR (1993) Biological control of purple loosestrife. Bioscience 43:680-686. https://doi.org/10.2307/1312339

McAvoy TJ, Kok LT, Johnson N (2016) A multiyear year study of three plant communities with purple loosestrife and biological control agents in Virginia. Biol Control 94:62-73. https://doi. org/10.1016/j.biocontrol.2015.12.007

Messick KS, Kerr D (2007) Garden loosestrife (Lysimachia vulgaris), a spreading threat in western waterways. In: Harrington TB, Reichard SH (eds) Meeting the challenge: invasive plants in Pacific Northwest ecosystems. Gen. Tech. Rep. PNW-GTR-694. U.S. Department of Agriculture, Forest Service, Pacific Northwest Research Station, Portland, OR, pp 53-57

Metsoja J-A (2016) Vegetation dynamics in floodplain meadows: influence of mowing and sediment application. Dissertationes Biologicae Universitatis Tartuensis 302. University of Tartu Press, Tartu. https://core.ac.uk/download/pdf/79116004.pdf. Accessed 26 September 2020
Mitchley J, Willems JH (1995) Vertical canopy structure of Dutch chalk grasslands in relation to their management. Vegetatio 117:17-27. https://doi.org/10.1007/BF00033256

Morozowska M (2004) Preliminary studies on seed germination and changes in foliage of Lysimachia vulgaris L. in garden culture. Rocz AR Poznań CCCLXIII Bot 7:201-207

Niczyporuk A, Wiater J (2006) The influence of basin use of Chwiszcza and Perebel River on seasonal quality of discharge water. Pol J Environ Stud 15:397-400

NRCS (2006) Pest management-invasive plant control purple loosestrife-Lythrum salicaria. Conservation Practice Job Sheet NH-595. https://www.nrcs.usda.gov/Internet/FSE_DOCUM ENTS/stelprdb1081652.pdf. Accessed 11 January 2021

OECD (2016) Farm management practices to foster green growth. OECD green growth studies. OECD Publishing, Paris

Oksanen L (2001) Logic of experiments in ecology: is pseudoreplication a pseudoissue? Oikos 94:27-38. https://doi.org/10. 1034/j.1600-0706.2001.11311.x

Pärtel M, Bruun HH, Sammul M (2005) Biodiversity in temperate European grasslands: origin and conservation. Grassl Sci Eur 10:1-14

Peach M, Zedler JB (2006) How tussocks structure sedge meadow vegetation. Wetlands 26:322-335. https://doi.org/10.1672/02775212(2006)26[322:HTSSMV]2.0.CO;2

Pierzgalski E, Boczoń A, Tyszka J (2002) Zmienność opadów i położenia wód gruntowych w Białowieskim Parku Narodowym. Kosmos 51:415-425

Poschlod P, Biewer H (2005) Diaspore and gap availability are limiting species richness in wet meadows. Folia Geobot 40:13-44. https://doi.org/10.1007/BF02803041

Prach K (2008) Vegetation changes in a wet meadow complex during the past half-century. Folia Geobot 43:119-130. https://doi.org/ 10.1007/s12224-008-9011-z

Rosenthal G (1992) Erhaltung und Regeneration von Feuchtwiesen. Vegetationsökol Untersuch Dauerfl Diss Bot 182:1-283

Schaffers AP (2002) Soil, biomass and management of semi-natural vegetation. Part II. Factors controlling species diversity. Plant Ecol 158:247-268. https://doi.org/10.1023/A:1015545821845

Schrautzer J, Asshoff M, Mueller F (1996) Restoration strategies for wet grasslands in Northern Germany. Ecol Eng 7:255-278. https://doi.org/10.1016/S0925-8574(96)00021-3

Schrautzer J, Fichtner A, Huckauf A, Rasran L, Jensen K (2011) Long-term population dynamics of Dactylorhiza incarnata (L.) Soó after abandonment and re-introduction of mowing. Flora 206:622-630. https://doi.org/10.1016/j.flora.2010.11.008

Stammel B, Kiehl K, Pfadenhauer J (2003) Alternative management of fens: response of vegetation to grazing and mowing. Appl Veg Sci 6:245-254. https://doi.org/10.1111/j.1654-109X.2003. tb00585.x

Temu VW, Baldwin BS, Reddy KR, Riffell SK (2015) Harvesting effects on species composition and distribution of cover attributes in mixed native warm-season grass stands. Environments 2:167-185. https://doi.org/10.3390/environments2020167

Trąba Cz, Wolański P (2011) Zróżnicowanie florystyczne łąk związków Calthion i Alopecurion w Polsce - zagrożenia i ochrona. Woda-Środowisko-Obszary Wiejskie 11:299-313

Tye H (1991) The lowland grasslands of Central and Eastern Europe. Monographic Series No. 004. IUCN, East European Programme. ISBN: 2-8317-0081-7. https://portals.iucn.org/libra ry/sites/library/files/documents/EEP-ER-004.pdf. Accessed 18 December 2020

Tyszka J (2008) Hydrologiczne funkcje lasu w małych nizinnych zlewniach rzecznych. Prace Instytutu Badawczego Leśnictwa, Sękocin Stary

Valkó O, Török P, Matus G, Tóthmérész B (2012) Is regular mowing the most appropriate and cost-effective management 
maintaining diversity and biomass of target forbs in mountain hay meadows? Flora 207:303-309. https://doi.org/10.1016/j. flora.2012.02.003

Vogt-Schilb H, Munoz F, Richard F, Schatz B (2015) Recent declines and range changes of orchids in Western Europe (France, Belgium and Luxembourg). Biol Conserv 190:133-141. https://doi. org/10.1016/j.biocon.2015.05.002

Wahlman H, Milberg P (2002) Management of semi-natural grassland vegetation: evaluation of a long-term experiment in southern Sweden. Ann Bot Fennici 39:159-166

Warne A (2016) Purple Loosestrife (Lythrum salicaria) best management practices in Ontario. Ontario Invasive Plant Council, Peterborough, ON. http://www.ontarioinvasiveplants.ca/wpcontent/uploads/2016/07/Purple-Loosestrife-BMP-April-2016final.pdf. Accessed 6 April 2021
Whittle AJ, Lenhart S, Gross LJ (2007) Optimal control for management of an invasive plant species. Math Biosci Eng 4:101-112. https://doi.org/10.3934/mbe.2007.4.101

Wilcox DA (1989) Migration and control of purple loosestrife (Lythrum salicaria L.) along highway corridors. Environ Manage 13:365-370. https://doi.org/10.1007/BF01874916

Publisher's Note Springer Nature remains neutral with regard to jurisdictional claims in published maps and institutional affiliations. 